\title{
Influence of Literacy Education Programmes on Socio-economic Empowerment of Women in Edo and Delta States, Nigeria
}

\author{
Omobola O. Adelore \\ University of Ibadan, Ibadan, Nigeria
}

\author{
Caroline O. Olomukoro \\ University of Benin, Benin, Nigeria
}

\begin{abstract}
The study examined the influence of literacy education programmes on the socio-economic empowerment of women in Edo and Delta states, in the South South geopolitical zone of Nigeria. A sample of 1,022 women was randomly drawn from basic intermediate and post literacy classes organised by the Agency of Adult and Non-formal Education, non-governmental organisations (NGOs), and private institutions in the area under investigation. The outcome of the study showed a strong correlation between literacy education programmes and socio-economic empowerment of women. Women had more access to loan and credit facilities for their economic activities thereby leading to higher income. They were able to use family planning methods and witnessed tremendous improvement in their families' nutritional status. It was recommended that literacy promoters and policymakers should intensify public enlightenment programmes for more women to participate; post literacy programmes should be encouraged to prevent relapse into illiteracy; and above all, literacy programmes should be designed to meet the needs and aspirations of women to ensure sustainability of literacy programmes.
\end{abstract}

Keywords: literacy education, socio-economic empowerment, women, health, vocational, family planning and income

\section{Introduction}

Today's complex society is witnessing rapid changes in all spheres of life, as noted in the political, economic, occupational, social, cultural, and technological domains. Education, formal or non-formal, is seen as an instrument and considered to be the prime mover of changes conceived as development. A meaningful participation in development presupposes acquisition of knowledge and skills through literacy or education.

It is no longer in doubt that women constitute the majority of adult illiterates in the world. Corroborating this view, the United Nations Educational, Scientific, and Cultural Organization (UNESCO) (2006) Education for All Global Monitoring Report stated that there were 771,000,000 adult illiterates in the world today, and two-thirds of them were women. The report (UNESCO, 2006) further pointed out that a large number of world illiterates were concentrated in the developing countries. Indeed, three quarters of them lived in just 12 countries, Nigeria inclusive.

The empowering role of literacy and its significance on development have been recognised worldwide noting that Nigeria, by 2006 national census figure, had over 40,000,000 illiterates, of which, 60\% were women, thereby placing Nigeria among the countries to over half of the world's population as well as to almost half of

Omobola O. Adelore, Ph.D., associate professor, Department of Adult Education, University of Ibadan.

Caroline Olomukoro, Ph.D., Lecturer I, Department of Adult and Non-formal Education, University of Benin. 
the world's out-of-school children and two thirds of the world's illiterates. The population of women in Nigeria was about 68,300,000 according to 2006 census report and two-thirds of them were illiterates. To participate effectively and meaningfully in the developmental process, they need to be empowered in all ramifications, especially in the socio-economic dimension since it is established that a high correlation exists between poverty and illiteracy. Most women, especially those in rural areas, are poverty stricken. Illiteracy keeps women marginalised, in this perspective, empowerment is key to reversing this. Women need more access to educational opportunities, skills acquisition, and positions of authority to be empowered. This is because harmonious and sustainable development requires the participation of all citizens of a nation. There will be no sustainable development when women do not enjoy equal rights and opportunities.

It must be emphasised that a nation cannot make impressive progress in terms of development if her womenfolk remained ignorant, excluded, and marginalised. Bokova (2010) lent support to this viewpoint, that there is no justification for denying women education. It is a basic right and an absolute condition for reaching all the internationally agreed development goals (Education for All, Millennium Development Goals, and Vision 2020).

In developing countries, according to ActionAid International (2005), it is estimated that each extra year of education a mother receives reduces her children's mortality rate by an average of 7\%-9\%. Better educated mothers are more likely to receive antenatal care; and their children are less likely to be malnourished. Literacy empowers women and it is the basis for the full promotion and improvement of the status of women. It is the basic tool that should be given to women to fulfil their role as bonafide members of the society (United Nations, 1985). In addition, studies show that literacy is critical in empowering women in all aspects of their lives. It improves livelihood, leads to a better child management and material health, as well as favours girls' access to education. Literacy gives women a voice in their families, political life, and on the world stage. It is a first step towards personal freedom and broader prosperity. When women are literate, the whole society gains (Bokova, 2010). To this end, the import of literacy cannot be overemphasised, as it remains the only basic tool for participating in learning of all kinds.

The provision of high quality literacy to about half of the population will improve lives and livelihood and will no doubt have sustainable social and economic impact on the womenfolk. Women over the years had limited access to educational opportunities and this has forestalled their contributions to national development. Increasingly, there is the realisation that sustainable human development cannot be effective if half of the human race remain ignorant and marginalised.

In this connection, the United Nations has been at the forefront of efforts to raise the status of women and bring them into the mainstream of development. For instance, the international women's year (1975), the United Nations decade for women (1976-1985), and the world conferences held at Mexico (1975), Copenhagen (1980), Nairobi (1985), and Beijing (1995) have all contributed to promoting gender equality and women empowerment. This was based on the notion that full integration of women in all aspects of political, economic, and social life, at the international, regional, and national levels, is essential, if obstacles to the achievement of the goals and objectives of the decade for women are to be overcome.

The 4th World Conference on Women held in Beijing, China, in September 1995, called for equal participation and partnerships between men and women in nearly all areas of public and private life. This conference has remained a compass for the evolution of women empowerment and the Beijing Platform for 
Action adopted at the conference remains the blueprint for promoting gender equality and women empowerment globally.

On the Nigeria scene, some laudable policies and programmes have been embarked upon in an attempt to elevate the status of women and bring them into core issues of development. Adult and non-formal education programmes have been put in place by the Nigerian government to improve women's participation in education. These include women's education programmes, mass literacy programmes, activities of the non-governmental organizations (NGOs), as well as private individual initiatives.

In 1989, the National Commission for Women was established to formulate a national policy on women and development. It is on this commission that all other programmes for women hinge. In 1986, the blueprint on women education in Nigeria was launched, followed by the setting up of women education units at federal and state ministries of education for rural and urban women who desired to further their education. The overall aim of the blueprint is to avail women equal educational opportunities irrespective of their age, locality, creed, or social status.

Another commission which promotes the interest of women especially educationally is the National Commission for Mass Literacy Adult and Non-formal Education (NMEC) set up in 1991 by the federal government, charged with the task of eradicating illiteracy in the country. Women are especially targeted in the programmes of the commission with mass literacy classes being conducted in all nooks and crannies of the country. In order to reach every part of the country, the commission creates agencies known as the Agency for Adult and Non-formal Education in all the states of the federation, Edo and Delta states inclusive.

Other programmes worthy of mentioning include Better Life for Rural Women established by the late first lady of the country, Mrs. Maryam Babangida. This programme played the role of raising consciousness of the rural Nigerian women, a crucial step towards their empowerment. This programme has filled a yearning gap in the lives of rural women. Additionally, the family support programme, Mass Mobilisation, Social Justice, and Economy Recovery (MAMSER), and more recently, the Women Trafficking Child Labour Eradication Foundation (WOTCLEF), were programmes put in place to empower women by transforming them into "assertive beings" rather than "being for others".

Women organisations are also widespread throughout the country, such as the National Council for Women Societies (NCWS), Women in Nigeria (WIN), National Association of Women Journalists (NAWOJ), and so on. Research outfits also sprang up to rise to the challenges of women and these include: Women in Research and Documentation Centre (WORDOC) established in 1986 at the Institute of African Studies, University of Ibadan, Association of African Studies Research and Development; and the Council for the Development of Economic and Social Research in Africa (CODESRIA), which all contribute to the enlistment of women (Egunyomi, Fadeyi, Folaranmi, \& Adelore, 2001).

In Edo and Delta states, literacy education programmes are being organised by government establishments, NGOs, and private institutions. For example, there are over 400 literacy centres in Edo State and several women education centres where women are being trained on skills and knowledge acquisition. Similarly, Delta State has over 500 literacy centres, 16 vocational, and several women education centres where women acquire skills in different vocational activities, such as dressmaking, knitting, embroidery, soap making, and catering. Women education centres empower them to meet their domestic and public obligations.

Literacy empowers and it is the most essential of all educational skills. Education, formal or non-formal, is 
the basis for the full promotion and improvement of women status. Moreover, education empowers women by improving their living standard (Olomukoro, 2012). Empowerment, according to Laoye (1999), is a training process through which participants acquire skills in some vocational activities, decision-making, literacy, and effective participation in governance. Empowering women will equip them with the much needed skills and provide them access to information and services to build capacity.

Available studies conducted in Nigeria have focused more on how vocational skills and higher education and continuing education programmes have improved the lots of women. Few studies, therefore, seem to have investigated the impact of literacy programmes on the socio-economic empowerment of women. In view of this, a study to examine whether adult literacy programmes in Nigeria are having the desired impact on the socio-economic empowerment of women is desirable.

\section{Research Question}

This study is guided by the research question: Is there any significant relationship between literacy education programmes and earning power of women in Edo and Delta states?

\section{Hypotheses}

$\mathrm{H}_{01}$ : There is no significant joint and relative effect of beginners, intermediate, and post literacy classes of literacy programmes on socio-economic empowerment of women;

$\mathrm{H}_{02}$ : There is no significant correlation between literacy education programmes and women adoption of family planning programmes.

\section{Theoretical Framework}

The study is hinged on the Human Capital Theory. This theory explains that investment in education increases one's efficiency in the labour market and results in higher earnings (Becker, 1964). Tachibanaki (1994) reported that higher educational attainment had led to higher occupational attainment. In other words, increased responsibility at work and better occupational attainment had led to higher earnings. This theory maintains that education should not be viewed simply as consumption, but rather, as a productive investment.

Bryant (1990) (as cited in Reynolds \& Weagley, 2003) defined human capital as an individual's knowledge, skills, and productive abilities. Although consensus on the issue of Human Capital Theory does not exist, some studies (Lockhead, Jamison, \& Lau, 1980; Psacharopoulos, 1985) revealed that investment in education has led to increased productivity, opportunity to secure higher paying jobs, and have brought about economic growth.

The Human Capital Theory focuses on skills acquisition through education as a means of empowering women which will lead to self-development and socio-economic status. Human Capital Theory focuses on capacity building premised on the notion that "There is presumed economic return on investment in education; that is skill or capacity based at the micro and macro levels" for the individual learner, such an investment seems to provide returns in the form of individual skills acquisition, benefits of literacy and its application for economic success and achievement (Blaug, 1970; 1976; Karabel \& Halseu, 1977; as cited in Akintayo \& Oghenekohwo, 2004).

The human capital is relevant to this study, because it lays emphasis on the investment of people through educational activities for skills acquisition, which will ultimately lead to capacity building and subsequent empowerment through skill ultilisation. Without investment in human capital, skills will not be acquired and 
there cannot be self-development and improved socio-economic status (Olomukoro, 2012). There is therefore a need to deliberately empower women with skills and knowledge through literacy education programmes. Arguably, it is through formal knowledge or literacy skills that women are able to take control of their lives and participate effectively in the developmental process.

The socio-economic aspects of women empowerment deal with the productive (income generating activities) and reproductive (nurturing children and improving family health). Access to education/literacy improves the economic empowerment of women especially in a country like Nigeria, where employment depends solely on certificates and degrees. To this end, an empowerment model (see Figure 1) has been developed using literacy programmes as intervention.

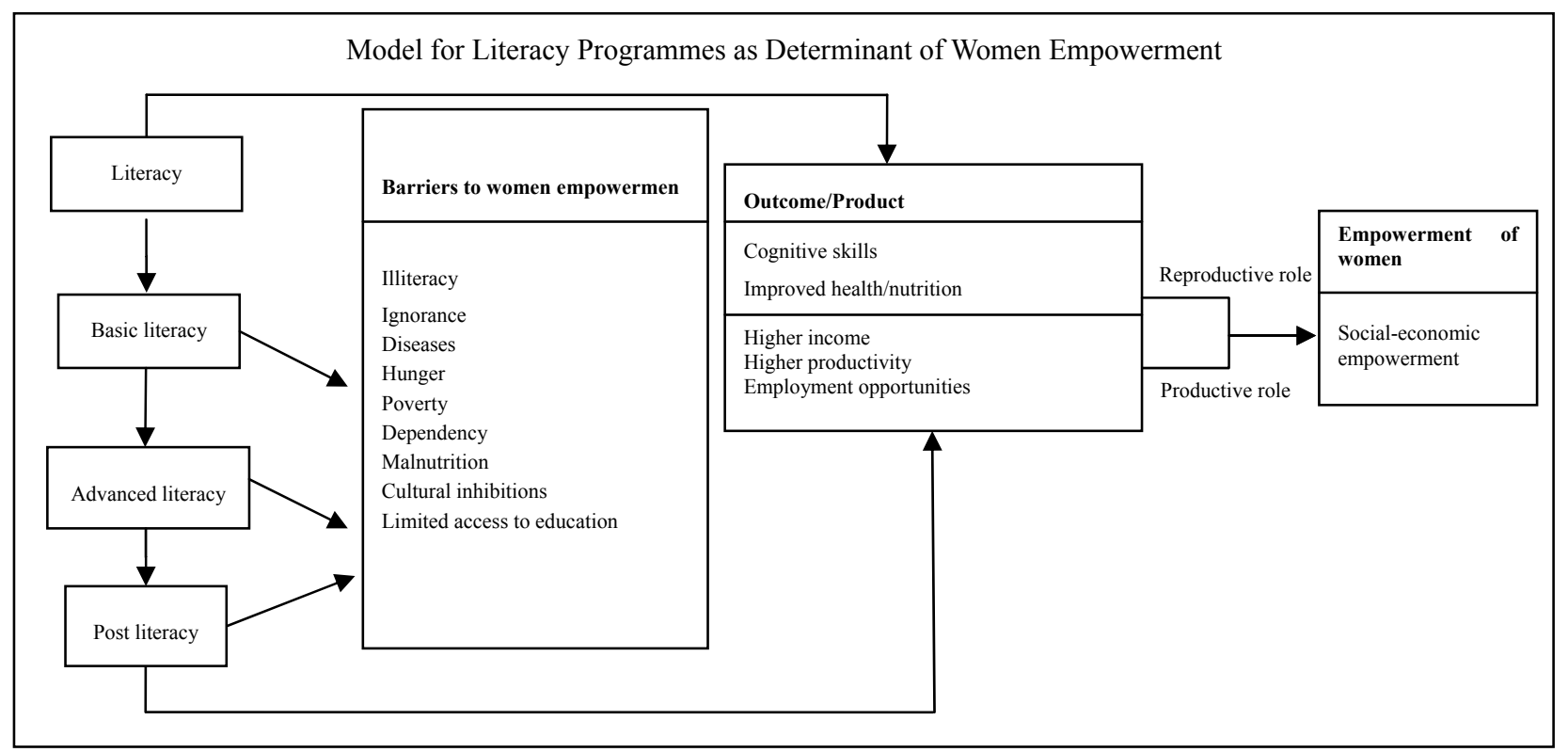

Figure 1. Literacy model for women empowerment (Olomukoro (2012) adapted and modified from Human Capital Theory, coats feminist, and Karl's (1994) empowerment theories).

\section{Methodology}

The study employed the descriptive survey research design. Stratified and random sampling techniques were used in selecting 1,022 women in 14 local government areas covering 26 literacy centres in Edo State and 28 literacy centres in Delta State.

The major instrument used was a structured questionnaire tagged "Women Socio-economic Empowerment Scale" (WSEES). The questionnaire was designed to have two sections. Section A was on the demographic characteristics of the respondents. Section B was structured on a 4-point rating scale of "Strongly agree" (SA), "Agree" (A), "Disagree" (D), and "Strongly disagree" (SD). This section was designed to elicit information on the effect of literacy programmes on socio-economic empowerment of women.

The content validity of the instrument was established by cross checking, verification, and consultation with experts in adult literacy education. Reliability was established through the test re-test method. A reliability coefficient of 0.76 was obtained by subjecting the data to Pearson's moment correlation coefficient.

The data collected were analysed using percentages, Pearson product-moment correlation, and multiple regression. 


\section{Results}

\section{Effects of Literacy Programmes (Beginners' Class, Intermediate Class, and Post Literacy Course) on Socio-economic Empowerment of Women}

Table 1 shows a significant contribution of beginners' class, intermediate class, and post literacy class to the socio-economic empowerment of women $\left(F_{(3,10,18)}=17.569 ; R=0.222, R^{2}=0.049\right.$, adjusted $R^{2}=0.046$; $p<0.05)$.

Table 1

Multiple Regressions of the Joint and Relative Effects of Literacy Programmes on Socio-economic Empowerment of Women

\begin{tabular}{|c|c|c|c|c|c|c|c|c|c|}
\hline Variable & $F$-ratio & Sig. of $p$ & $R$ & $R^{2}$ & Adj. $R^{2}$ & $\beta$ & Ranking & $t$ & $p$ \\
\hline Beginners' class & & & & & & 0.099 & $3 \mathrm{rd}$ & 2.249 & 0.025 \\
\hline Intermediate class & 17.569 & 0.000 & 0.222 & 0.049 & 0.046 & 0.136 & 2nd & 4.069 & 0.000 \\
\hline Post literacy level & & & & & & 0.039 & $1 \mathrm{st}$ & 0.873 & 0.383 \\
\hline
\end{tabular}

The calculated $F$-ratio was found to be significantly higher than the critical $F$-ratio of 1.75 at 0.05 level of significance. The null hypothesis is therefore rejected as given the significant relationship between socio-economic empowerment of the women and the three independent variables.

The relative contributions show that while post literacy level ranked first $(\beta=0.136 ; p<0.05)$, intermediate ranked second $(\beta=0.099 ; p<0.05)$, and beginners' class ranked third $(\beta=0.039 ; p<0.05)$.

\section{Literacy Education Programmes and Earning Power of Women}

Table 2 indicates that a significant correlation exists between literacy education programmes and earning power of women. The $r$-value is 0.285 , which is less than the alpha level of 0.05 . Since the $r$-value is less than the alpha level of 0.05 , the result is considered significant. This indicates that literacy education programmes correlated with the earning power of women.

Table 2

Pearson's Test of Relationship Between Literacy Education Programmes and the Earning Power of Women

\begin{tabular}{lllllll}
\hline Variable & Mean & $S D$ & $N$ & Pearson's $r p$ & Remark \\
\hline Literacy education programmes & 34.7935 & 5.6210 & \multirow{2}{*}{1,022} & \multirow{2}{*}{$0.285^{* *}$} & \multirow{2}{*}{0.000} & Significant \\
Earning power of women & 11.1614 & 3.4341 & & & \\
\hline
\end{tabular}

Note. ${ }^{* *}$ Significant at 0.05 level.

\section{Literacy Education Programmes and Women Adoption of Family Planning Methods}

Table 3 indicates a significant correlation between literacy education attainment and women adoption of family planning methods. The $r$ value of 0.590 is less than the alpha level of 0.05 , the result is significant. The null hypothesis is rejected. Consequently, the alternate which states that there is a significant correlation between literacy education attainment and women adoption of family planning methods is upheld.

Table 3

Pearson's Test of Relationship Between Literacy Education Programmes and Women Adoption of Family Planning Methods

\begin{tabular}{llll}
\hline Factor & $N$ & Pearson's $r$ & $p$ value \\
\hline $\begin{array}{l}\text { Women literacy education attainment } \\
\text { Adoption of family planning methods }\end{array}$ & 1,022 & $0.590^{* *}$ & 0.000 \\
\hline
\end{tabular}

Notes. $\alpha=0.05 ;{ }^{* *} p<0.05$. 


\section{Discussion}

Literacy programmes were categorised into three levels in the study (The beginners' class, the intermediate, and the post literacy or advanced). The study reveals that literacy education programmes jointly and significantly influenced women's socio-economic empowerment $\left(F_{(3,10,18)}=17.57 ; p<0.05\right)$, as shown in Table 1. The relative significant contributions of the different literacy levels to women's socio-economic empowerment show that the post literacy level is the most potent $(\beta=0.136 ; p<0.05)$, followed by the intermediate level $(\beta=0.099 ; p<0.05)$, and lastly, by the beginners' level $(\beta=0.039 ; p<0.05)$. This implies that the higher the literacy skills of the women, the greater the ability to participate in socio-economic activities. This affirms the Human Capital Theory's view that the basic adult literacy education enhances the productivity of workers in low skill occupations while high or professional positions demand specialised knowledge and logical and analytical reasoning.

The joint contributions of beginners, intermediate, and post literacy programmes of literacy education is also in line with Human Capital Theory that education is basically a form of investment in labour force. The rate of development of a nation is related to its investment in this human resource. It emphasises that investment in people through educational activities could lead to skill acquisition, capacity building, and optimal skill utilisation that are pertinent to participation in the developmental process. The proponent of this theory (Schultz, 1961) posits that education does not only improve the choices available to individuals, but provides them type of skills necessary for industrial development and economic growth.

It should be noted that at the post literacy level, the participants can study independently, comprehend and put into practice the skills they have acquired at a higher level. They can also easily retain their literacy skills.

The intermediate level focuses on the practical aspect that is the functional activities. The participants have acquired basic skills to enable them engage in vocational tasks they perform on a daily basis. At the basic level, the learners were exposed to the skills of reading, writing, and calculating for the first time that is those who had little formal schooling not sufficient to perform skills for their day to day activities. They are most concerned with cognitive skills they needed at their level (knowledge of alphabets, reading, writing, spelling, speaking, and so on).

It should however be emphasised that literacy even at a very basic level, can be rendered meaningfully as well as functionally and thus, transfer to other domains of social life. Corroborating this view, Akinpelu (2002) described alphabetic literacy as the most fundamental foundation and tool for all forms of worthwhile and sustainable development.

It is also observed that literacy education programmes correlate significantly with women's higher income $(r=0.285)$. The finding supports Institute for Lifelong Learning (UIL) $(2013 ; 2014)$ that a strong correlation exists between increased literacy and higher life-time earnings. Besides, studies have shown that literacy education programmes have been found to have a positive impact on self-development and women income status; just as education has consistently be a major determinant of individual income, alongside professional experience (Hannum \& Buchmann, 2003). Education for All Global Monitoring Report (UNESCO, 2006) shows that literacy has a positive impact on earnings, beyond the impact of the quality of schooling. In addition, Jellema and Unterhalter (2005) maintained that education equips girls and women with a basic confidence in their abilities and rights, such as to acquire and process information as well as increase earning power. They further stated that education is a key economic asset for individuals and nations. Every year of schooling lost 
represents a $10 \%-20 \%$ reduction in girls' future incomes. From the study, women attested to the fact that participating in literacy programmes had given them greater access to loan (54.3\%); to run their trade, increased their earning power (income) (65.5\%); and made them contribute more meaningfully to the household income (66.7\%). Reducing economic dependency can be a basis for empowerment for women. It could therefore be inferred from this study that literacy education programmes have contributed significantly to the higher income levels of women in the two states under study.

The study also indicates that literacy education programmes correlate significantly with adoption of family planning methods $(r=0.590)$. The finding is consistent with the views of Sandiford, Cassael, and Sanchez (1995), who observed that infant mortality fell by a statistically significant amount among Nicaraguan mothers who had participated in an adult literacy campaign than those who did not, and the reduction was greater for those made literate in the campaign than for those made literate in the primary school. It has also been noted that acquisition of skills in schools especially literacy leads to women exposure to information concerning health and contraceptive services (R. A. Levine, Dexter, Velasco, S. Levine, Joshi, \& Stuebing, 1994).

Further, studies have shown that increase in female schooling including adult literacy has been followed by declining child mortality and fertility in subsequent decades. Association of female education with birth and death rates is among the most regularities uncovered by quantitative social science (Hobcraft, 1993; Jejeebhoy, 1995; Maduogu, 2012; UIL, 2014). Educated women tend to marry late, thus, depress fertility and may adopt more health-promoting domestic child care practices that reduce mortality, but are also consistently more likely to use maternal and contraceptive services.

In addition, Burchfield, Hau, Iturry, and Rocha (2002) revealed that Bolivia women who attended literacy and basic education programmes displayed gains in health-related knowledge and behaviour, unlike women who did not participate in such programmes. Buttressing the finding further, U.S. Department of Health and Human Services (2005) indicated a high positive connection between literacy, health, and family planning. Literacy skill was found to have a positive impact on the health and family planning practices of women in Nepal and increased their ability to communicate effectively with the health workers about the needs and the condition of their children, which helped in enhancing their ability to understand health information presented to them orally or on radio.

Studies, such as U.S. Department of Health and Human Services (2005) and Kirchbush (2011), in developing countries pointed to the effects of literacy on health status. For example, literate women are found to enjoy a higher status in the family than non-literate women. They also use more family planning techniques and have fewer and healthier children than non-literate women. It can therefore be said without gainsaying that literacy education attainment had a very strong impact on women adoption of family planning techniques as it has helped them adopt preventive health measures, such as immunisation $(81 \%)$, participation in family planning programmes $(71 \%)$, and increased nutritional status of the family $(91 \%)$.

\section{Conclusion}

The study has established a strong correlation between literacy education programmes and socio-economic empowerment of women in the area investigated. Women had greater access to loan and credit facilities for their economic activities; they were able to use family planning methods, such as immunization, and witnessed tremendous improvement in the family nutritional status. They were able to read at the basic level and that the more the literacy skills, the more their capacity to participate in society. This implies that literacy skills impact 
immediate benefits on recipients and it is a veritable tool for social, economic, and political emancipation. Consequently, government, international development partners, and other stakeholders in education should ensure that the use of literacy programmes to empower women is accorded high priority.

\section{Recommendations}

Based on the findings, the following recommendations are made:

1. Literacy programmes should be designed to meet the needs of women. Skill acquisition is the best option for empowerment of women at the grassroots. Therefore, literacy providers and policymakers should ensure that functional skills are incorporated into the curriculum of literacy programmes to help women actualise their potentials and ensure sustainability of literacy programmes;

2. Post-literacy programmes should be encouraged to prevent relapse into illiteracy for it is at this level that literacy skills can be made permanent and functional;

3. Public enlightenment programmes should be intensified to create more awareness and mobilise illiterate women for literacy programmes, so that the effects can be more widespread, thereby, giving policymakers and literacy programmes' stakeholders enough impetus to invest in literacy education.

\section{References}

ActionAid International. (2005). Writing the wrongs: International benchmarks on adult literacy. London, U.K.: ActionAid International.

Akinpelu, J. A. (2002). Philosophy and adult education. Lagos: Stirling-Horden Publishers (Nig.) Ltd..

Akintayo, M. O., \& Oghenekohwo, J. E. (2004). Developing adult education and community development: New paradigms. Ibadan: Educational Research and Study Group.

Becker, G. S. (1964). Human capital: A theoretical and empirical analysis with special reference to education. Chicago, I.L.: The University of Chicago Press.

Bokova, I. (2010). Forward in UNESCO \& International Social Science Council World Social Science Report: Knowledge divides. Paris: UNESCO Publishing. Retrieved from http://www.unesco.org/shs/wssr

Burchfield, S., Hua, H., Iturry, T., \& Rocha, V. (2002). A longitudinal study of the effect of integrated literacy and basic education programmes on the participation of women in social and economic development in Nepal. Boston, M.A.: United States Agency for International Development Office of Women in Development.

Egbo, B. (2000). Gender, literacy and life chances in Sub-Saharan Africa. Cleveland/Buffalo/Sydney: Multilingual Matters.

Egunyomi, D., Fadeyi, T., Folaranmi, F., \& Adelore, O. (2001). Women and development in rethinking adult and non-formal education. In J. T. Okedara, C. N. Anyanwu, \& M. A. Omole (Eds.), Rethinking adult and non-formal education: A book of readings in memory of Professor Ayo Ogunseye. Ibadan: Stirling-Horden Publishers.

Hannum, E., \& Buchman, C. (2003). The consequences of global educational expansion. Cambridge, M.A.: American Academy of Arts and Sciences.

Hobcraft, J. (1993). Women's education, child welfare and child survival: A review of the evidence. Health Transition Review, 3, 159-175.

Institute for Lifelong Learning (UIL). (2013). Literacy programmes with a focus on women to reduce gender disparities: Case studies from UNESCO effective literacy and numeracy practices database (Litbase). Hamburg: UNESCO/UIL. Retrieved from http: //www.unesco.org/uil/litbase/

Jejeebhoy, S. (1995). Women's education autonomy and reproductive behaviour: Experience from developing countries. Oxford, U.K.: Clarendon Press.

Jellema, A., \& Unterhalter, E. (2005). Girls can't wait: Why girls education matters and how to make it happen how. Adult Education and Development, 65, 83-94.

Kabeer, N. (1999). Resources, agency achievements: Reflections on the measurement of women's empowerment. Development and Change, 30, 435-484. 
Kirchbush, I. (2011). Health literacy: Addressing the health and education divide. Health Promotion International Promotion International, 16(3), 289-297

Laoye, A. A. (1999). The experience of university village association in income generating activities and women literacy participation in Oyo State, 1989-1997 (Unpublished Ph.D dissertation, Department of Adult Education, University of Ibadan).

Levine, R. A., Dexter, E., Velasco, P., Levine, S., Joshi, A. R., \& Stuebing, K. W. (1994). Maternal literacy and health care in three countries: A preliminary report. Health Transition Review, 4, 186-191.

Lockhead, M. E., Jamison, D. T., \& Lau, L. J. (1980). Farmer education and form proficiency: A survey in World Bank staff (Working Paper No. 402). Washington, D. C.: World Bank.

Maduogu, C. A. (2012). Literacy needs of non-literate women in Benue state of Nigeria. International Journal of Social Science and Education, 2(2), 176-185.

Olomukoro, C. O. (2012). Influence of literacy education programmes on socio-economic and psychological empowerment of women in Edo and Delta states, Nigeria (Unpublished Ph.D. dissertation, Faculty of Education, University of Ibadan).

Psacharopoulos, G. (1985). Returns to education: A further international update and implications. Journal of Human Resources, 20, 583-604.

Reynolds, L. M., \& Weagley, R. O. (2003). Academic persistence in higher education. Consumer Interests Annual, 49, 1-8.

Sandiford, P. J., Cassel, M., \& Sanchez, G. (1995). The impact of women's literacy on child health and its interaction with access to health services. Population Studies, 49, 5-17.

Schultz, T. W. (1961). Education and economic growth. In N. B. Henry (Ed.), Social forces influencing American education. Chicago, I.L.: University of Chicago Press.

Shrestha, C. K. (1997, May 5-9). Women's literacy: The connection to health and family planning. Paper presented at The Asia Literacy Regional Forum, Manila, Philippines.

Tachibanaki, T. (1994). The international encyclopedia of education. Oxford, U.K.: Pergamon Press.

UIL. (2014). Gender equality matters: Empowering women through literacy programmes (UIL Policy Brief 3). Hamburg: UNESCO/UIL.

United Nations. (1985). The Nairobi forward-looking strategies for the advancement of women. Nairobi: United Nations.

United Nations Educational, Scientific, and Cultural Organization (UNESCO). (2006). Education for all global monitoring report: Literacy for life. Paris: UNESCO.

UNESCO. (2008). Education for all global monitoring report: Education for all by 2015. Paris: UNESCO.

U.S. Department of Health and Human Services. (2005). Communicating health: Priorities and strategies for progress. Retrieved January 31, 2012, from http://www.odphp.osophs.dhhs.gov./projects/HealthComm/objective2.htm 